Article

\title{
Larvicidal and Enzymatic Inhibition Effects of Annona Muricata Seed Extract and Main Constituent Annonacin against Aedes Aegypti and Aedes Albopictus (Diptera: Culicidae)
}

\author{
Alzeir Machado Rodrigues $1,2, * \mathbb{C}$, Antonio Adailson Sousa Silva ${ }^{3}$, \\ Cleonilda Claita Carneiro Pinto ${ }^{2}$, Dayanne Lima dos Santos ${ }^{4}$, José Claudio Carneiro de Freitas ${ }^{5}$, \\ Victor Emanuel Pessoa Martins ${ }^{6}$ and Selene Maia de Morais ${ }^{7, *}$ \\ 1 Departamento de Ensino, Ciências e Formação de Professores, Instituto Federal de Educação, \\ Ciência e Tecnologia do Pará, Avenida Almirante Barroso, 1155, Belém 66093-020, Pará, Brazil \\ 2 Programa de Pós-Graduação em Biotecnologia, RENORBIO, Universidade Estadual do Ceará, \\ Avenida Doutor Silas Munguba, 1700, Fortaleza 60741-000, Ceará, Brazil \\ 3 Programa de Pós-Graduação em Farmacologia, Universidade Federal do Ceará, Rua Coronel Nunes de \\ Melo, 1127, Fortaleza 60430-275, Ceará, Brazil \\ 4 Laboratório de Química de Produtos Naturais, Universidade Estadual do Ceará, Avenida Doutor Silas \\ Munguba, 1700, Fortaleza 60741-000, Ceará, Brazil \\ 5 Vertrauen Diagnosis, Avenida Washington Soares, 655, Fortaleza 60810-000, Ceará, Brazil \\ 6 Instituto de Ciências Exatas e da Natureza, Universidade da Integração Internacional da Lusofonia \\ Afro-Brasileira (Unilab), Campus das Auroras, Rua José Franco de Oliveira s/n, Redenção 62790-970, \\ Ceará, Brazil \\ 7 Departamento de Química, Universidade Estadual do Ceará, Avenida Doutor Silas Munguba, 1700, \\ Fortaleza 60741-000, Ceará, Brazil \\ * Correspondence: alzeir.rodrigues@ifpa.edu.br (A.M.R.); selene.morais@uece.br (S.M.d.M.); \\ Tel.: +55-85-3191-9961 (S.M.d.M.)
}

Received: 19 June 2019; Accepted: 20 July 2019; Published: 26 July 2019

\begin{abstract}
The mosquitoes Aedes aegypti and Aedes albopictus are vectors of arboviruses that cause dengue, zika and chikungunya. Bioactive compounds from plants are environmentally sustainable alternatives to control these vectors and thus the arboviruses transmitted by them. The present study evaluated the larvicidal activity of an acetogenin-rich fraction (ACERF) and its main constituent annonacin obtained from Annona muricata seeds on Ae. aegypti and Ae. albopictus. The larvicidal assays were performed using different concentrations to calculate the $\mathrm{LC}_{50}$ and $\mathrm{LC}_{90}$ values observed $24 \mathrm{~h}$ after exposure to the treatment. Annonacin was more active against Ae. aegypti $\left(\mathrm{LC}_{50} 2.65 \mu \mathrm{g} \cdot \mathrm{mL}^{-1}\right)$ in comparison with Ae. albopictus $\left(\mathrm{LC}_{50} 8.34 \mu \mathrm{g} \cdot \mathrm{mL}^{-1}\right)$. In contrast, the acetogenin-rich fraction was more active against $A$ e. albopictus $\left(\mathrm{LC}_{50} 3.41 \mu \mathrm{g} \cdot \mathrm{mL}^{-1}\right)$ than $A$ e. aegypti $\left(\mathrm{LC}_{50} 12.41 \mu \mathrm{g} \cdot \mathrm{mL}^{-1}\right)$. ACERF and annonacin treated larvae of Ae. aegypti and Ae. albopictus showed significant differences in the inhibition of their metabolic enzymes when compared to untreated larvae. The results demonstrate the relevant larvicidal action of the acetogenin-rich fraction and annonacin showing the potential to develop new products for the control of Ae. aegypti and Ae. albopictus.
\end{abstract}

Keywords: Aedes; larvicidal; botanicals; annonacin

\section{Introduction}

Aedes aegypti Linnaeus (Diptera: Culicidae) is the main vector of arboviruses such as those that cause dengue, zika and chikungunya, diseases that affect all continents, although they are more 
frequent in tropical and subtropical countries [1,2]. At the same time, Aedes albopictus Skuse (Diptera: Culicidae), originating in Southeast Asia, is vector of diseases such as dengue, yellow fever and encephalitis, among other diseases [3]. In Brazil, its presence has been identified in almost all states [4], and it is considered a secondary vector of arboviruses in the country. Although vaccines against dengue serotypes are being developed [5], the presence of other viruses transmitted by Aedes spp. reinforces the need to control their vectors [6]. These mosquitoes have a broad capacity to adapt to the environment [7]. One of the most effective control strategies is the use of synthetic insecticides for the elimination of immature or adult stages (larvicides and insecticides) [8], although their frequent use has triggered the selection of resistant strains [9].

However, many plants contain bioactive compounds, which are environmentally safe for use as alternatives in the control of Ae. aegypti and Ae. albopictus, since these secondary metabolites are biodegradable [10]. This characteristic of natural products is important in the search for new environmentally safe phytopesticides for the control of immature stages of Aedes [11]. Thus, resistance of these disease vectors to current pesticides is a growing problem, and products from plants are eco-sustainable alternatives in this respect $[12,13]$. Many plant products have been evaluated against Ae. aegypti [14] and those from Annonaceae family show the best action [15]. The Annonaceae family is composed of a diverse group of angiosperms, including 2500 distinct species [16]. Annona muricata L. (Annonaceae), known as graviola or soursop, is a common edible fruit plant grown in Brazil [17]. Its fruits produce a significant number of seeds and its pulp is widely appreciated. Acetogenins (ACGs) are substances often found among the constituents of the Annonaceae family. Such compounds are characterized by the presence of an aliphatic chain with 35 to 38 carbons, attached to an $\alpha, \beta$-unsaturated $\gamma$-lactone ring substituted with a methyl terminal, in addition to the presence of one or two tetrahydrofuran (THF) and/or tetrahydropyran (THP) rings along the hydrocarbon chain. The chain contains a specific number of oxygenated groups (hydroxyl, acetoxyl, ketone and epoxy) $[18,19]$. In A. muricata, annonacin is the acetogenin most reported to be present [18-21], being considered major component of this species.

Then, the objective of this study was to evaluate the larvicidal activity of an acetogenin-rich fraction and the main constituent, annonacin, against Ae. aegypti and Ae. albopictus, major vectors of arboviruses, as well as analyzing changes in the vital protein activity of these mosquitoes after treatment with the natural product.

\section{Materials and Methods}

\subsection{Seed Collection and Obtaining the Ethanolic Extract of Annona muricata}

A. muricata fruits were provided by the company Flora Boa, located in the town Limoeiro do Norte, Ceará, Brazil. The seeds (500 g) were sun dried and triturated, then macerated for 7 days with $96 \%$ ethanol. After this period, the ethanol solution was filtered and concentrated in a vacuum rotary evaporator, to obtain the ethanol extract of A. muricata (EESAM).

\subsection{Obtaining the Acetogenin-Rich Fraction of A. muricata Seeds}

The EESAM was subjected to filtration through silica gel column chromatography, eluted with the solvents hexane, chloroform, ethyl acetate and methanol in mixtures of increasing polarity. The fractions eluted with chloroform and ethyl acetate were pooled based on the thin-layer chromatography (TLC) analysis, using Kedde's reagent (Solution A:3,5-dinitrobenzoic acid in 3\% methanol, and Solution B: $5.7 \% \mathrm{KOH}$ in water, in the ratio of 1:1), to obtain an acetogenin-rich fraction (ACERF).

\subsection{Analysis of the Acetogenin-Rich Fraction by HPLC and Separation of Its Main Constituent}

The analyses were performed with Shimadzu high-performance liquid chromatograph in reverse phase, with an SCL-10Avp controller system, SPD-10Avp UV-Vis detector and LC-10Atvp gradient pump, under the following chromatographic conditions: flow rate of $1 \mathrm{ml}$ per minute at a wavelength 
of $214 \mathrm{~nm}$, mobile phase in the gradient mode of a solution composed of deionized water and methanol (15\%:85\%) up to $40 \mathrm{~min}$, and (5\%:95\%) up to $60 \mathrm{~min}$, oven temperature of $40{ }^{\circ} \mathrm{C}, 20 \mu \mathrm{L}$ loops, and CLC-ODS M C18 column $(250 \mathrm{~mm} \times 4.6 \mathrm{~mm})$.

To separate the constituents, $200 \mathrm{mg}$ of ACERF was dissolved in $20 \mathrm{~mL}$ of methanol. An aliquot of $1 \mathrm{~mL}$ was withdrawn from that solution and dissolved in $10 \mathrm{~mL}$ of methanol for injection in an analytical high-performance liquid chromatograph equipped as follows: SLC-10AVP controller system, SPD-10AVP UV-Vis detector, and LC-10-ATVP isocratic pump. The column used was a Shimpack CLC-ODS M (C18), measuring $250 \mathrm{~cm} \times 4.6 \mathrm{~mm} \mathrm{D}$, employing a wavelength of $214 \mathrm{~nm}$, run time of $30 \mathrm{~min}$, flow rate of $1 \mathrm{~mL}$ per minute, mobile phase composed of $87 \%$ spectroscopic methanol and $13 \%$ deionized water, injection of $20 \mu \mathrm{L}$, and oven temperature of $40{ }^{\circ} \mathrm{C}$. An aliquot of the ACERF solution $(12 \mathrm{~mL})$ was injected and the main fraction was collected separately. This procedure was repeated several times. Then, the fractions collected were concentrated in a rotary evaporator and lyophilized to obtain annonacin, whose chemical structure was characterized by nuclear magnetic resonance spectroscopy.

The purity of the main constituent of the ACERF, identified as annonacin, was determined by injection in a liquid chromatograph in analytical mode. For this purpose, a $0.84 \mathrm{mg} / \mathrm{mL}$ solution of fraction 2 in methanol was prepared and the following system was used: Shimadzu preparative high-performance liquid chromatograph with SCL-10Avp controller system, SPD-10Avp UV-Vis detector, and LC-10Atvp gradient pump, under the following chromatographic conditions: flow rate of $1 \mathrm{ml}$ per minute at a wavelength of $214 \mathrm{~nm}$, mobile phase in the gradient mode of a solution composed of deionized water and methanol (15\%:85\%); up to $40 \mathrm{~min}$ and (05\%:95\%) up to $60 \mathrm{~min}$, oven temperature of $40^{\circ} \mathrm{C}, 20 \mu \mathrm{L}$ loop and CLC-ODS M C18 column $(250 \mathrm{~mm} \times 4.6 \mathrm{~mm})$.

\subsection{Collection and Maintenance of Ae. aegypti and Ae. albopictus Mosquitoes}

During the dengue control program in Fortaleza, Ceará, ovitraps are used to collect Ae. aegypti and Ae. albopictus eggs. Positive ovitraps were sent to the Entomology Laboratory (LE) of Federal University of Ceará for eggs to hatch. The larvae were obtained from a colony of successive generations maintained at the insectarium of the LE. These larvae were kept under controlled conditions of temperature $\left(25 \pm 2{ }^{\circ} \mathrm{C}\right)$, relative humidity $(80 \pm 10 \%)$ and light and dark photoperiod (12:12) in plastic containers holding $1000 \mathrm{~mL}$ of distilled water, and were fed with fish meal until reaching the third and fouth instars.

\subsection{Larvicidal Assay}

The larvicidal tests were performed at concentrations of $0.5,1,5,10,20,25,50$ and $75 \mu \mathrm{g} \cdot \mathrm{mL}^{-1}$ of ACERF and annonacin from A. muricata, all of which were performed in triplicate. The ACERF and annonacin at different concentrations were diluted in a solution of $5 \%$ dimethyl sulfoxide (DMSO) and 95\% distilled water, and a negative control was also tested with DMSO and water. Twenty larvae were included in each test and mortality was verified after $24 \mathrm{~h}$ of exposure [22].

\subsection{Enzymatic Effect of the Acetogenin-Rich Fraction and Annonacin of A. muricata on the Mosquito Larvae}

The enzymatic assays were performed using a Bioplus Bio-200 biochemical analyzer. The action of ACERF and annonacin on the larvae of Ae. aegypti and Ae. albopictus exposed at a concentration of $25 \mu \mathrm{g} \cdot \mathrm{mL}^{-1}$ during $24 \mathrm{~h}$ was verified from the analysis of the main enzymes of the metabolism of Culicidae larvae by adaptation of the method of Suryawanshi et al. [23]. The enzymes assayed were alkaline phosphatase, acid phosphatase, proteases, esterases and amylases. All experiments were performed with larval stages.

\subsection{Statistical Analysis}

The $\mathrm{LC}_{50}$ values (concentration that kills $50 \%$ of larvae and pupae) and $\mathrm{LC}_{90}$ (concentration that kills $90 \%$ of larvae) were obtained from probit analysis using the SPSS statistical software. Analysis of 
variance (ANOVA) was used to investigate the existence of significant differences in the parameters of the enzymatic activities of treated and untreated mosquito larvae after ACERF and annonacin application $(p<0.05)$. The normality criterion was applied to the variables and the Tukey test was used to verify where the differences occurred in the studied groups.

\section{Results and Discussion}

\subsection{Analysis of the Constituents of the Acetogenin-Rich Fraction (ACERF)}

In the TLC analysis of the various ACERF fractions obtained in the chromatographic column (those that revealed a characteristic pink color with Kedde's reagent) were collected and the chromatogram of HPLC analysis (Figure 1) presented several peaks with similar UV spectra (Figure 2). The ACERF was subjected to semi-preparative HPLC fractionation to separate the main acetogenin constituent with a retention time of $9.6 \mathrm{~min}$. The major substance was separated and analyzed by nuclear magnetic resonance, and was revealed to be annonacin (Figure 3) by comparison with spectral data reported in the literature for this substance [24].

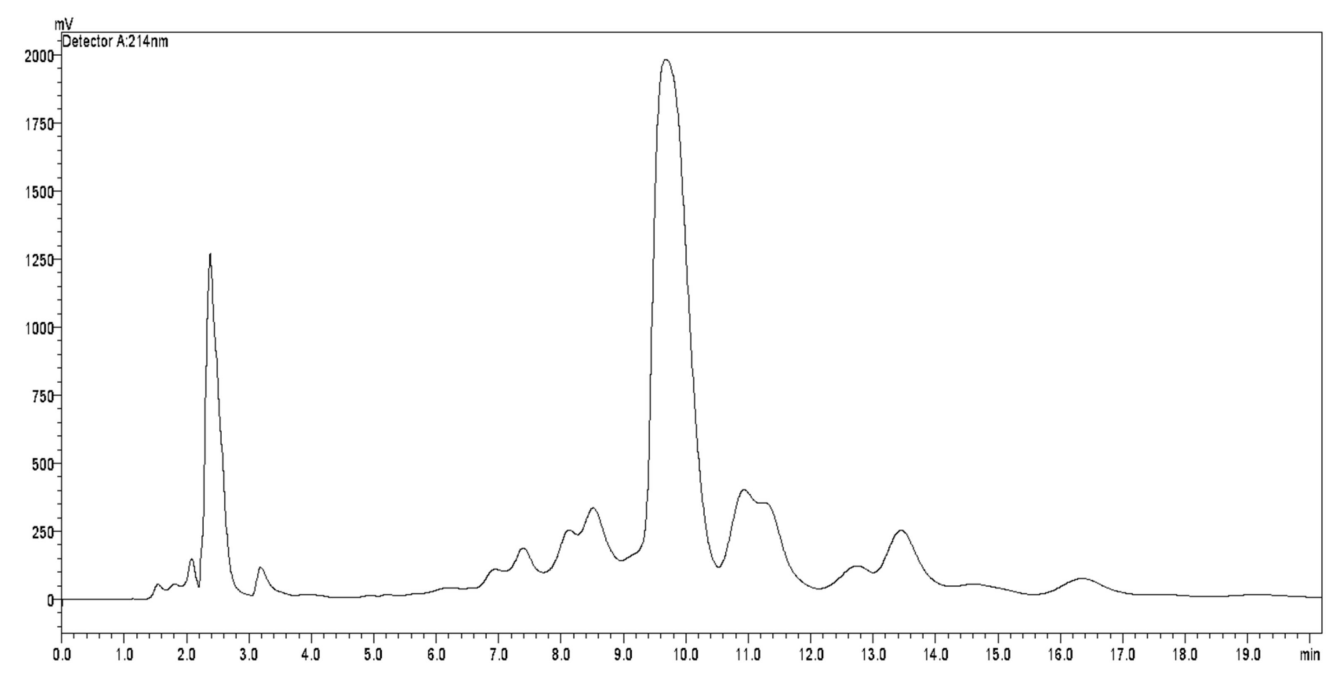

Figure 1. Chromatogram of the ACERF.

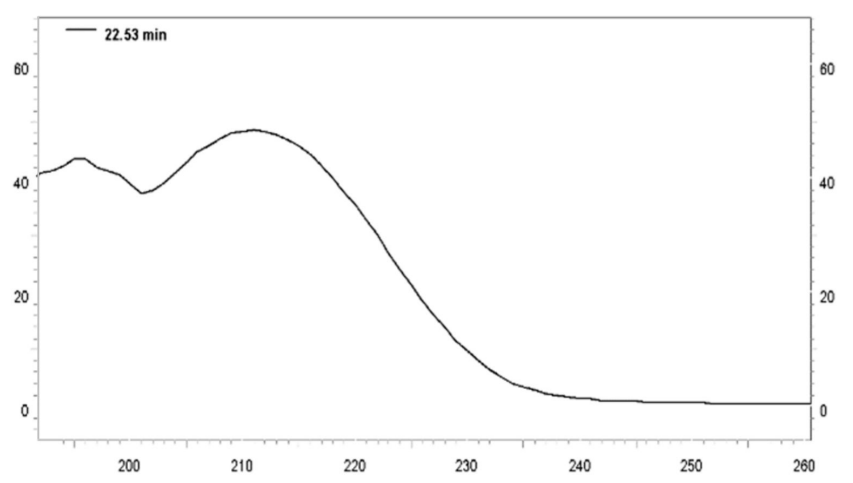

Figure 2. UV curve of the main acetogenin isolated from the acetogenin-rich extract of $A$. muricata.

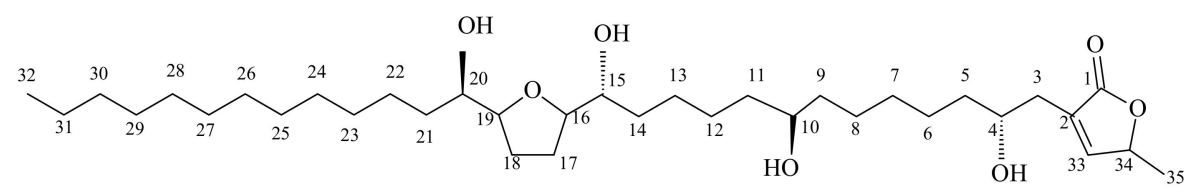

Figure 3. Representation of chemical structure of annonacin. 


\subsection{Efficacy of the ACERF and Annonacin of A. muricata Seeds on Ae. aegypti and Ae. albopictus}

The larvicidal action of the acetogenin-rich fraction of $A$. muricata seeds is shown in Table 1 . The $\mathrm{LC}_{50}$ of ACERF for Ae. albopictus was $3.41 \mu \mathrm{g} \cdot \mathrm{mL}^{-1}$ - the best result in relation to other strains. The Ae. aegypti (Rockefeller strain) showed highest resistance to treatment with ACERF of A. muricata, with $\mathrm{LC}_{50}$ and $\mathrm{LC}_{90}$ values, respectively, of 26.75 and $54.46 \mu \mathrm{g} \cdot \mathrm{mL}^{-1}$, as determined by the probit analysis. Concentrations higher than $50 \mu \mathrm{g} \cdot \mathrm{mL}^{-1}$ were responsible for $100 \%$ mortality of Ae. albopictus and concentrations higher than $75 \mu \mathrm{g} \cdot \mathrm{mL}^{-1}$ were totally lethal to the other strains.

Table 1. Lethal concentration of the fraction rich in acetogenins of $A$. muricata against fourth instar larvae of Ae. aegypti and Ae. Albopictus.

\begin{tabular}{ccc}
\hline Mosquito Strains & $\mathbf{L C}_{\mathbf{5 0}} \mathbf{( C L}$ at $\left.\mathbf{9 5} \%\right)$ & LC $_{\mathbf{9 0}}$ (CL at 95\%) \\
\hline Ae. aegypti & $12.41(9.85-14.86)$ & $30.21(26.17-36.52)$ \\
Ae. albopictus & $3.41(2.83-4.00)$ & $6.17(5.37-7.43)$ \\
Ae. aegypti (Rockefeller strain) & $26.75(21.36-34.00)$ & $54.46(44.78-71.01)$
\end{tabular}

Control: no mortality. As the level of significance is greater than 0.05 , no heterogeneity factor was used in the calculation of confidence limits. $\mathrm{LC}_{50}$ : concentration that kills $50 \%$ of the exposed larvae (in $\mu \mathrm{g} \cdot \mathrm{mL}^{-1}$ ) with confidence limit at $95 \%$. LC 90 : concentration that kills $90 \%$ of the exposed larvae (in $\mu \mathrm{g} \cdot \mathrm{mL}^{-1}$ ) with confidence limit at $95 \%$.

A study of the leaf extract from other Annonaceae plants, such as A. reticulata, reported effective action against $A$ e. aegypti larvae, with $\mathrm{LC}_{50}$ and $\mathrm{LC}_{90}$ values of 95.24 and $262.64 \mu \mathrm{g} \cdot \mathrm{mL}^{-1}$, respectively [25]. The hexane extract of the leaves of $A$. muricata gathered in Tarlac City (Philippines) showed the highest toxicity, with $\mathrm{LC}_{50}$ value of $25.99 \mu \mathrm{g} \cdot \mathrm{mL}^{-1}$ and $\mathrm{LC}_{90}$ value of $49.47 \mu \mathrm{g} \cdot \mathrm{mL}^{-1}$, while the ethanol extract yielded $\mathrm{LC}_{50}$ of $46.36 \mu \mathrm{g} \cdot \mathrm{mL}^{-1}$ and $\mathrm{LC}_{90}$ of $195.39 \mu \mathrm{g} \cdot \mathrm{mL}^{-1}$. Characterization of the ethanol extract showed the presence of flavonoids (leucoanthocyanidins), condensed tannins, unsaturated steroids, triterpenoids, and fats and oils.

Regarding the strain of Ae. albopictus, Kempraj and Bhat [26] reported the larvicidal action of the acetone soluble fraction of the ethanolic extract of $A$. squamosa seeds, with respective $\mathrm{LC}_{50}$ and $\mathrm{LC}_{90}$ values of 5.26 and $38.37 \mu \mathrm{g} \cdot \mathrm{mL}^{-1}$, on fourth instar larvae. The authors also performed tests of ovicidal and adulticide activity, as well as tests to verify the effect of the A. squamosa extracts on oviposition of females, with toxicity observed in all trials.

The plants of the Annonaceae family show high toxicity to Aedes spp. larvae. The larvicidal activities against $A$ e. aegypti have been determined in the ethanolic extracts obtained from 51 Brazilian medicinal plants. Eleven of the 84 extracts studied showed significant $\left(\mathrm{LC}_{50}<100 \mu \mathrm{g} \cdot \mathrm{mL}^{-1}\right)$ activities against larvae, with extracts from $A$. crassiflora (root bark, $\mathrm{LC}_{50}=0.71 \mu \mathrm{g} \cdot \mathrm{mL}^{-1}$; root wood, $\mathrm{LC}_{50}=$ $8.94 \mu \mathrm{g} \cdot \mathrm{mL}^{-1}$ and A. glabra seed, $\mathrm{LC}_{50}=0.06 \mu \mathrm{g} \cdot \mathrm{mL}^{-1}$, showing the highest activities [27].

Natural products from plants of other families (Myrtaceae, Rutaceae, Euphorbiaceae, Piperaceae, Asteraceae and Liliaceae) in general are less active. The essential oils of Eucalyptus cinerea had $\mathrm{LC}_{50}$ of $380 \mu \mathrm{g} \cdot \mathrm{mL}^{-1}$ [28], Citrus sinensis had $\mathrm{LC}_{50}$ of $446.84 \mu \mathrm{g} \cdot \mathrm{mL}^{-1}$ [29] and Piper gaudichaudianum had $\mathrm{LC}_{50}$ of $121 \mu \mathrm{g} \cdot \mathrm{mL}^{-1}$ [30]. Various solvent extracts of stems, roots and leaves of Parthenium hysterophorus showed low efficacy, with $\mathrm{LC}_{50}$ above $400 \mu \mathrm{g} \cdot \mathrm{mL}^{-1}$ [31], and Aloe vera, with $\mathrm{LC}_{50}$ of $300.06 \mu \mathrm{g} \cdot \mathrm{mL}^{-1}$ [32]. The $\mathrm{LC}_{50}$ values of petroleum ether extracts of Jatropha curcas, Piper tithymaloides, Phylantus amarus, Euphorbia hirta, and E. tirucalli were 8.79, 55.26, 90.92, 272.36, and $4.25 \mu \mathrm{g} \cdot \mathrm{mL}^{-1}$, respectively, against $A$ e. aegypti and $11.34,76.61,113.40,424.94$, and $5.52 \mu \mathrm{g} \cdot \mathrm{mL}^{-1}$, respectively, against $C$ quinquefasciatus [33].

Annonacin is considered an environmental neurotoxin and is found in the pulp of several fruits of the Annonaceae family, whose consumption has been linked to the occurrence of sporadic atypical Parkinsonism with dementia. A method for its quantification in rat brain homogenates by UPLC-MS/MS was developed and validated. This method was applied to the quantitation of annonacin in rat brains after intravenous $(0.5 \mathrm{mg} / \mathrm{kg})$ and oral $(10 \mathrm{mg} / \mathrm{kg}, 100 \mathrm{mg} / \mathrm{kg})$ administration. Nevertheless, annonacin appeared to have very low distribution in rat brains by both routes [34]. 
Annonacin was shown to be significantly active against Ae. aegypti (Rockefeller strain), presenting lower lethal concentrations than those observed for the acetogenin-rich fraction $\left(\mathrm{LC}_{50} 2.65 \mu \mathrm{g} \cdot \mathrm{mL}^{-1}\right.$; $\left.\mathrm{LC}_{90} 4.83 \mu \mathrm{g} \cdot \mathrm{mL}^{-1}\right)$. The larvae of Ae. albopictus presented $\mathrm{LC}_{50}$ of $8.34 \mu \mathrm{g} \cdot \mathrm{mL}^{-1}$ and $\mathrm{LC}_{90}$ of $16.30 \mu \mathrm{g} \cdot \mathrm{mL}^{-1}$ (Table 2).

Table 2. Lethal concentration of annonacin from A. muricata against fourth instar larvae of Aedes spp.

\begin{tabular}{ccc}
\hline Mosquito Strains & LC $_{\mathbf{5 0}}$ (CL at 95\%) & LC $_{\mathbf{9 0}}$ (CL at 95\%) \\
\hline Ae. aegypti (Rockefeller strain) & $2.65(1.87-3.64)$ & $4.83(3.80-7.35)$ \\
Ae. albopictus & $8.34(7.10-10.26)$ & $16.30(13.56-21.13)$ \\
\hline
\end{tabular}

Control: no mortality. As the level of significance is greater than 0.05 , no heterogeneity factor was used in the calculation of confidence limits. $\mathrm{LC}_{50}$ : concentration that kills $50 \%$ of the exposed larvae (in $\mu \mathrm{g} \cdot \mathrm{mL}^{-1}$ ) with confidence limit at $95 \%$. $\mathrm{LC}_{90}$ : concentration that kills $90 \%$ of the exposed larvae (in $\mu \mathrm{g} \cdot \mathrm{mL}^{-1}$ ) with confidence limit at $95 \%$.

According to the literature, the larvicidal action against mosquitoes of Annonaceae plant extracts is comparable to that reported for pure acetogenins [27]. The ethanolic extract of $A$. glabra had $\mathrm{LC}_{50}$ of $27 \mu \mathrm{g} \cdot \mathrm{mL}^{-1}$ against Ae. aegypti larvae [35], in contrast to isolated acetogenins such as goniothalamin, gigantriocin and longimicin, with $\mathrm{LC}_{50}$ values of $13.3 \mu \mathrm{g} \cdot \mathrm{mL}^{-1}, 18.5 \mu \mathrm{g} \cdot \mathrm{mL}^{-1}$ and $27.3 \mu \mathrm{g} \cdot \mathrm{mL}^{-1}$, respectively [36].

The high activity of ACERF and annonacin against larvae of Ae. aegypti and Ae. albopictus enables the use of low amounts. The small distribution of this substance in the rat brain, conferring low toxicity, justifies the use in phytotherapic preparations as larvicidal agents.

\subsection{Changes in the Enzymatic Level of Ae. aegypti and Ae. albopictus Treated with ACERF and Annonacin}

The mechanism of action of natural products on Aedes spp. larvae has been investigated in recent studies [1,37]. Among the explanations of this mechanism are the ultrastructural alterations of organs such as anal papillae [38], intestinal and tracheal system damage [1], inhibition of enzymatic activity [39], and morphological aberrations [40]. In this study, we investigated the effect of ACERF and annonacin on the inhibition of proteins important for the development of Aedes spp. larvae.

The one-way ANOVA showed that ACERF has an effect on the total proteins between the groups $(p<0.05)$. The Tukey test showed the yield of total proteins of Ae. albopictus treated with ACERF was significantly different from the control and Ae. aegypti. However, there was no difference between the control group and the treated Ae. aegypti (Figure 4A).

Alkaline phosphatase activity was altered by ACERF treatment $(p<0.05)$. The Tukey test indicated no difference between the control group and Ae. aegypti strain, however, both groups were significantly different from Ae. albopictus (Figure 4B). Similarly, there was a change in the enzymatic effect of acid phosphatase $(p<0.05)$, but it was the only significant difference between Ae. albopictus and control (Figure 4C).

Among the proteases, there was a difference between the groups $(p<0.05)$. This difference, when verified by the post-hoc Tukey test, was significant between Ae. albopictus and the control and Ae. aegypti (Figure 4D). Differences were also observed between groups in relation to esterase activity $(p<0.05)$, with a significant increase in the activity of these enzymes in strain Ae. albopictus compared to the other enzymes - which were similar to each other-as verified by the Tukey test (Figure 4E).

The ACERF also elicited significant changes between groups with respect to amylase activity $(p<0.05)$, and the larval strain Ae. albopictus showed a significant reduction compared to the control and to Ae. aegypti (Figure 4F).

The consistent changes in the enzymatic activity of Ae. albopictus $\left(\mathrm{LC}_{50}=3.41 \mu \mathrm{g} \cdot \mathrm{mL}^{-1}\right)$ treated with ACERF corroborate the greater larvicidal effect of this fraction in this species when compared to Ae. aegypti $\left(\mathrm{LC}_{50}=12.41 \mu \mathrm{g} \cdot \mathrm{mL}^{-1}\right)$. 
A

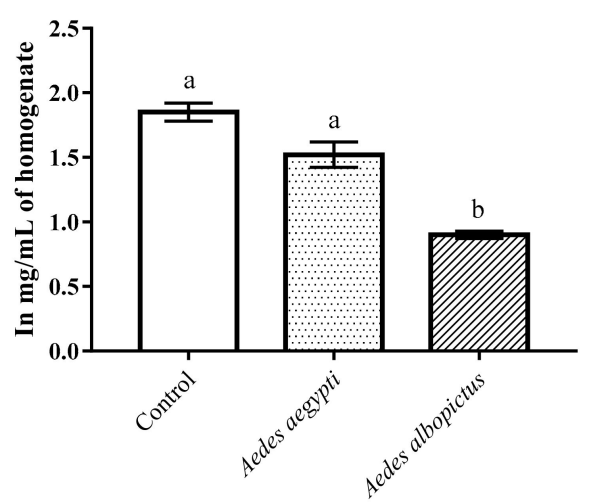

C

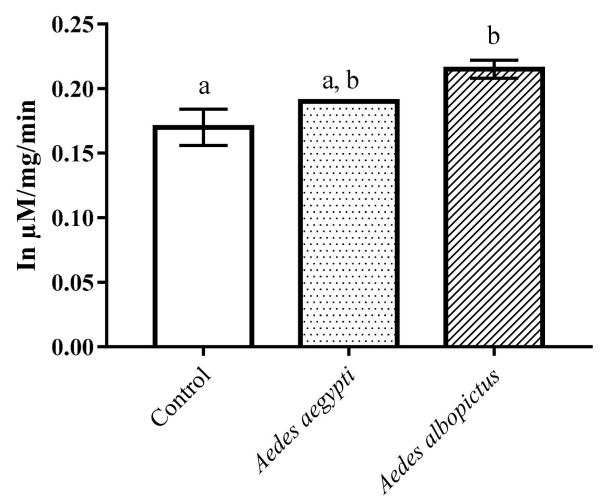

$\mathbf{E}$

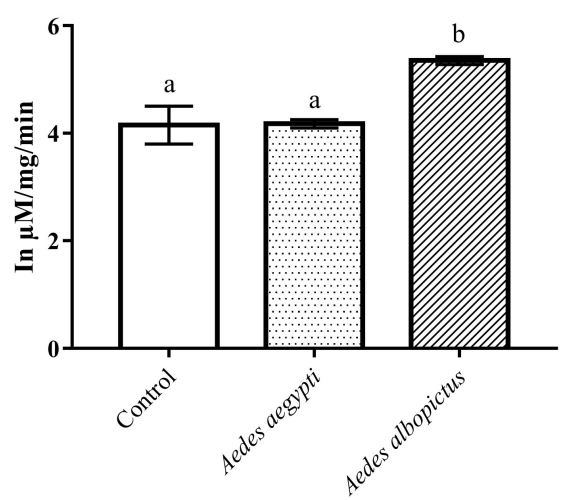

B Alkaline phosphatase

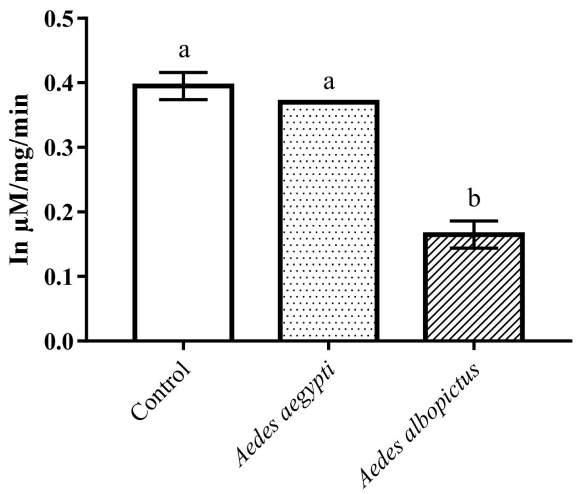

D Proteases

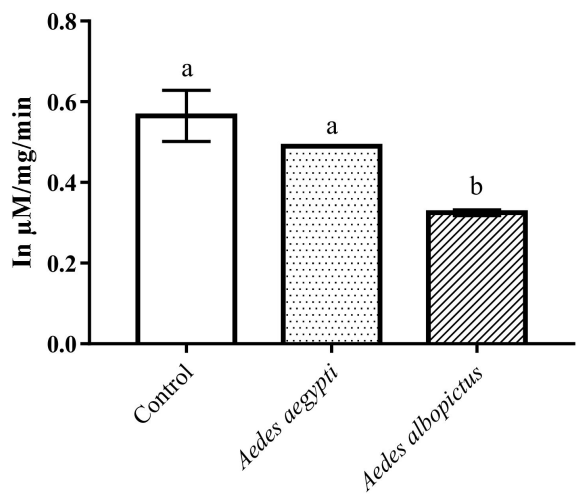

F

Amylases

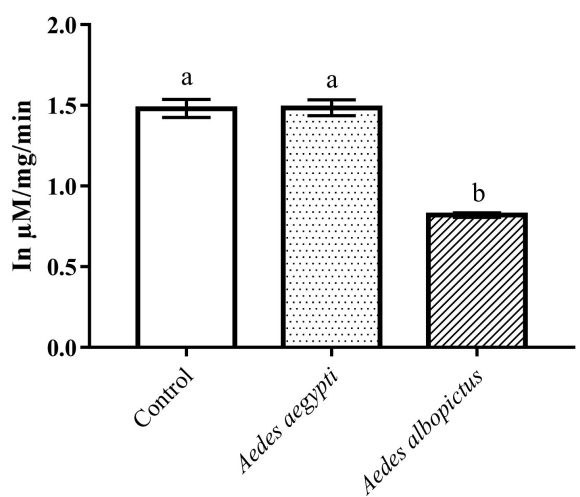

Figure 4. Enzymatic changes of total proteins (A), alkaline phosphatase (B), acid phosphatase (C), proteases $(\mathbf{D})$, esterases $(\mathbf{E})$ and amylases $(\mathbf{F})$ between larvae treated and untreated with the ACERF of A. muricata. Different lowercase letters on the bar denote significant difference $(p<0.05)$. Bar represent the standard deviations $(\mathrm{n}=2)$. Values estimated by one-way ANOVA followed by Tukey's test. Control: untreated larvae.

In relation to the treatment of Aedes larvae with annonacin, one-way ANOVA showed a significant difference between groups in activity of total protein $(p<0.05)$, alkaline phosphatase $(p<0.05)$ and esterase $(p<0.05)$. The Tukey post-hoc test confirmed that the activities of the total proteins, alkaline phosphatase and esterase of the control group were significantly different against Ae. aegypti (Rockefeller strain) and Ae. albopictus (Figure 5A,B,E). 
A

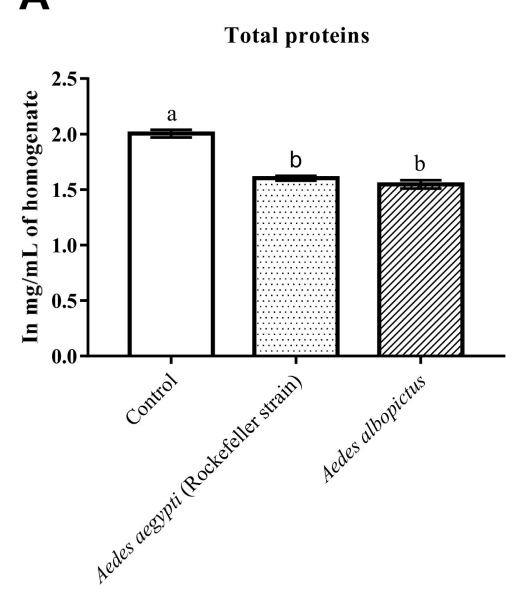

C
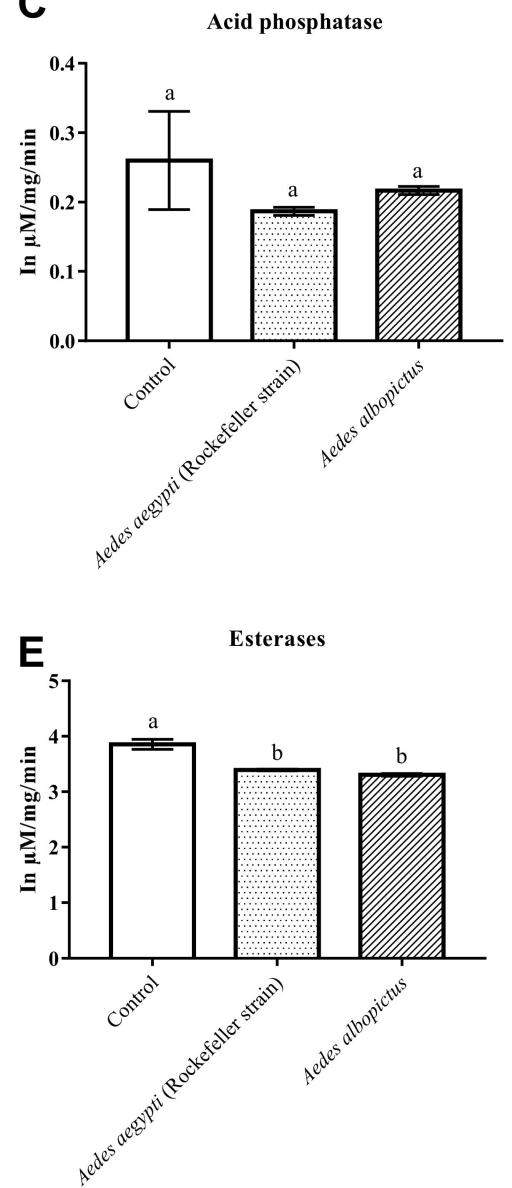

B Alkaline phosphatase

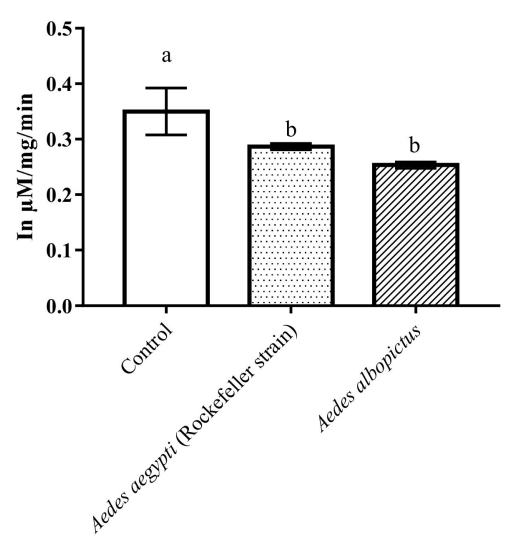

D
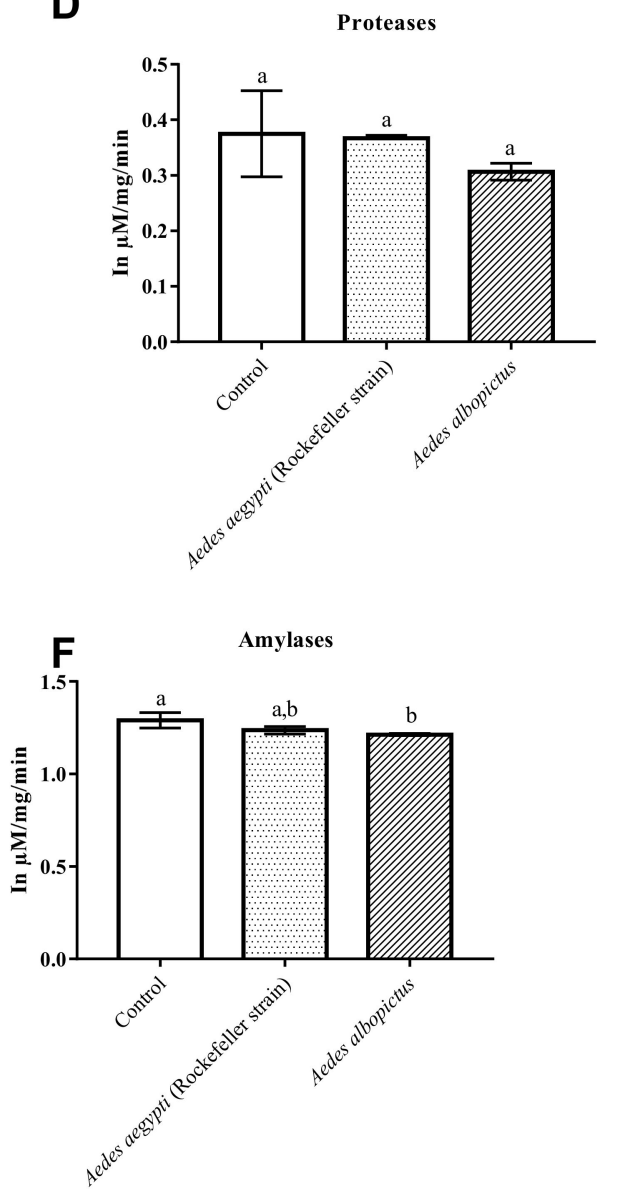

Figure 5. Enzymatic changes of total proteins (A), alkaline phosphatase (B), acid phosphatase (C), proteases $(\mathbf{D})$, esterases $(\mathbf{E})$ and amylases $(\mathbf{F})$ between larvae treated and untreated with the annonacin of A. muricata. Different lowercase letters on the bar denote significant difference $(p<0.05)$. Bar represent the standard deviations $(n=2)$. Values estimated by one-way ANOVA followed by Tukey's test. Control: untreated larvae.

There was no significant difference in the activity of acid phosphatase (Figure 5C) $(p>0.05)$ and protease (Figure 5D) $(p>0.05)$ between the control and treated groups. The amylase activity showed significant differences between the groups $(p<0.05)$. While the Tukey post-hoc confirmed significant 
differences only between the control and Ae. albopictus groups, the Ae. aegypti (Rockefeller strain) group did not present significant differences between these two groups (Figure 5F).

Similarly, studies of enzymatic changes in larvae and pupae of Ae. aegypti treated with the aqueous extract of Sapindus emarginatus Vahl. (Sapindaceae) showed that the activity of esterases and acid phosphatase were affected, and more noticeably in larvae than pupae [41].

Another study correlated the inhibitory capacity of a protease inhibitor from garlic (Allium sativum) with its larvicidal activity [42]. These authors considered that the reduction of $50 \%$ in the presence of digestive proteases by the A. sativum protease has biotechnological potential for the control of $A e$. aegypti. In this respect, ACERF of $A$. muricata caused a reduction in proteases of both treated strains and contributed to the inactivation of those proteins, which is detrimental for the survival of Aedes spp.

The larvicidal effect of ACERF was greater on larvae of Ae. albopictus than on other treated strains, whereas annonacin had a larvicidal activity greater in Ae. aegypti (Rockefeller strain). Regarding the inhibitory effect on the enzymes, differences were observed between ACERF and annonacin on total proteins, acid phosphatase and alkaline phosphatase in strains with greater susceptibility to natural products. These differences most likely result from the fact that in ACERF there are other acetogenins besides its major constituent-annonacin. These acetogenins are substances that act synergistically in the enzymatic inhibitory effect and in the larvicidal action, whereas in the isolated annonacin, we have the presence of a single substance that conditions specific effects on the larvae and their enzymes.

\section{Conclusions}

Ae. aegypti and Ae. albopictus exhibit different susceptibilities to the fraction rich in acetogenins and annonacin-the main constituent. In addition, ACERF-treated larvae of Ae. albopictus showed a significant difference in the activity of all the enzymes studied compared to control larvae, a fact that corroborates the relevant $\mathrm{LC}_{50}$ observed in the larvicidal tests of this lineage of the natural product in question. Regarding the treatment with annonacin, there were significant differences between treated and untreated larvae, however only for the activity of total proteins, alkaline phosphatase, esterase and amylase. This study indicates the promising potential of $A$. muricata as an alternative source of sustainable, biodegradable and environmentally safe natural product for the control of the dengue vectors Ae. aegypti and Ae. albopictus.

Author Contributions: Conceptualization, A.M.R. and S.M.d.M.; formal analysis, C.C.C.P.; investigation, D.L.d.S. and J.C.C.d.F.; methodology, A.M.R., A.A.S.S., C.C.C.P., D.L.d.S., J.C.C.d.F. and S.M.d.M.; project administration, S.M.d.M.; supervision, S.M.d.M.; writing—original draft, A.M.R. and S.M.d.M.; writing—review and editing, V.E.P.M.

Funding: This research received no external funding.

Acknowledgments: The authors thank the governmental agencies Funcap and CNPq by the financial support of a research project Ref. Proc. No 3781047/2017, Agreement 837577/2016, Calling 01/2017-Program for the SUS-PPSUS-Funcap-Decit/ACTIE/MS-CNPq.

Conflicts of Interest: The authors declare that there are no conflicts of interest.

\section{References}

1. Fujiwara, G.M.; Annies, V.; De Oliveira, C.F.; Lara, R.A.; Gabriel, M.M.; Betim, F.C.; Nadal, J.M.; Farago, P.V.; Dias, J.F.; Miguel, O.G.; et al. Evaluation of larvicidal activity and ecotoxicity of linalool, methyl cinnamate and methyl cinnamate/linalool in combination against Aedes aegypti. Ecotoxicol. Environ. Saf. 2017, 139, 238-244. [CrossRef]

2. De Oliveira, A.P.S.; Silva, L.L.D.S.; Lima, T.D.A.; Pontual, E.V.; Santos, N.D.D.L.; Coelho, L.C.B.B.; Navarro, D.M.D.A.F.; Zingali, R.B.; Napoleão, T.H.; Paiva, P.M.G. Biotechnological value of Moringa oleifera seed cake as source of insecticidal lectin against Aedes aegypti. Process. Biochem. 2016, 51, 1683-1690. [CrossRef]

3. Pezzi, M.; Zamberlan, F.; Chicca, M.; Leis, M. Evaluation of larvicidal activity of esters of 4-mercapto-2-butenoic acid against Aedes albopictus (Diptera: Culicidae). Saudi J. Boil. Sci. 2018. [CrossRef] 
4. Martins, V.E.P.; Martins, M.G.; De Araújo, J.M.P.; Silva, L.O.R.; Monteiro, H.A.D.O.; Castro, F.C.; Vasconcelos, P.F.D.C.; Guedes, M.I.F. First report of Aedes (Stegomyia) albopictus in the state of Ceará, Brazil. Rev. Saúde Pública 2006, 40, 737-739. [CrossRef] [PubMed]

5. Dayan, G.H.; Rivera, D.M.; Deseda, C.; Costa, M.S.; Morales-Ramírez, J.O.; Rey, L.C.; Dietze, R.; Luz, K.; Rivas, E.; Zambrano, B.; et al. Efficacy of a Tetravalent Dengue Vaccine in Children in Latin America. $N$. Engl. J. Med. 2015, 372, 113-123.

6. Karunaratne, S.; Weeraratne, T.; Perera, M.; Surendran, S. Insecticide resistance and, efficacy of space spraying and larviciding in the control of dengue vectors Aedes aegypti and Aedes albopictus in Sri Lanka. Pestic. Biochem. Physiol. 2013, 107, 98-105. [CrossRef] [PubMed]

7. Da Silva, V.C.; O Scherer, P.; Falcão, S.S.; Alencar, J.; Cunha, S.P.; Rodrigues, I.M.; Pinheiro, N.L. Diversidade de criadouros e tipos de imóveis freqüentados por Aedes albopictus e Aedes aegypti. Rev. Saúde Pública 2006, 40, 1106-1111. [CrossRef]

8. Rueda, A.G.; Otero, A.L.C.; Duque, J.E.; Kouznetsov, V.V. Synthesis of new $\alpha$-amino nitriles with insecticidal action on Aedes aegypti (Diptera: Culicidae). Rev. Bras. Ėntomol. 2018, 62, 112-118. [CrossRef]

9. Braga, I.A.; Valle, D. Aedes aegypti: Inseticidas, mecanismos de ação e resistência. Epidemiol. Serviços Saúde 2007, 16, 279-293. [CrossRef]

10. Park, H.-M.; Kim, J.; Chang, K.-S.; Kim, B.-S.; Yang, Y.-J.; Kim, G.-H.; Shin, S.-C.; Park, I.-K. Larvicidal activity of Myrtaceae essential oils and their components against Aedes aegypti, acute toxicity on Daphnia magna, and aqueous residue. J. Med. Èntomol. 2011, 48, 405-410. [CrossRef]

11. Ali, S.I.; Gopalakrishnan, B.; Venkatesalu, V. Chicory (Cichorium intybus) and wormwood (Artemisia absinthium) extracts exhibit strong larvicidal activity against mosquito vectors of malaria, dengue fever, and filariasis. Parasitol. Int. 2018, 67, 781-786. [CrossRef]

12. Mendes, L.A.; Martins, G.F.; Valbon, W.R.; De-Souza, T.D.S.; Menini, L.; Ferreira, A.; Ferreira, M.F.C. Larvicidal effect of essential oils from Brazilian cultivars of guava on Aedes aegypti L. Ind. Crops Prod. 2017, 108, 684-689. [CrossRef]

13. Oliveira, A.E.M.F.M.; Bezerra, D.C.; Duarte, J.L.; Cruz, R.A.S.; Souto, R.N.P.; Ferreira, R.M.A.; Nogueira, J.; Conceição, E.C.; Leitão, S.; Bizzo, H.R.; et al. Essential oil from Pterodon emarginatus as a promising natural raw material for larvicidal nanoemulsions against a tropical disease vector. Sustain. Chem. 2017, 6, 1-9. [CrossRef]

14. Piplani, M.; Bhagwat, D.P.; Singhvi, G.; Sankaranarayanan, M.; Balana-Fouce, R.; Vats, T.; Chander, S. Plant-based larvicidal agents: An overview from 2000 to 2018. Exp. Parasitol. 2019, 199, 92-103. [CrossRef] [PubMed]

15. Ramanibai, R.; Parthiban, E.; Boothapandi, M. Effect of seed kernel aqueous extract from Annona squamosa against three mosquito vectors and its impact on non-target aquatic organisms. Asian Pac. J. Trop. Dis. 2016, 6, 741-745. [CrossRef]

16. Ribeiro, L.P.; Vendramim, J.D.; Bicalho, K.U.; Andrade, M.S.; Fernandes, J.B.; Moral, R.A.; Demétrio, C.G.B. Annona mucosa Jacq. (Annonaceae): A promising source of bioactive compounds against Sitophilus zeamais Mots. (Coleoptera: Curculionidae). J. Stored Prod. Res. 2013, 55, 6-14. [CrossRef]

17. Bento, E.B.; Júnior, F.E.B.; De-Oliveira, D.R.; Fernandes, C.N.; De-Araújo-Delmondes, G.; Cesário, F.R.A.S.; Rodrigues, K.S.; Sales, V.S.; Figueiredo, F.R.S.D.N.; Lemos, I.C.S.; et al. Antiulcerogenic activity of the hydroalcoholic extract of leaves of Annona muricata Linnaeus in mice. Saudi J. Biol. Sci. 2018, 25, 609-621. [CrossRef] [PubMed]

18. Avula, B.; Bae, J.-Y.; Majrashi, T.; Wu, T.-Y.; Wang, Y.-H.; Wang, M.; Ali, Z.; Wu, Y.-C.; Khan, I.A. Targeted and non-targeted analysis of annonaceous alkaloids and acetogenins from Asimina and Annona species using UHPLC-QToF-MS. J. Pharm. Biomed. Anal. 2018, 159, 548-566. [CrossRef] [PubMed]

19. Coria-Téllez, A.N.; Montalvo-Gónzalez, E.; Yahia, E.M.; Obledo-Vázquez, E.N. Annona muricata: A comprehensive review on its traditional medicinal uses, phytochemicals, pharmacological activities, mechanisms of action and toxicity. Arab. J. Chem. 2016, 11, 662-691. [CrossRef]

20. Roduan, M.R.M.; Hamid, R.A.; Sulaiman, H.; Mohtarrudin, N. Annona muricata leaves extracts prevent DMBA/TPA-induced skin tumorigenesis via modulating antioxidants enzymes system in ICR mice. Biomed. Pharmacother. 2017, 94, 481-488. [CrossRef] [PubMed] 
21. Sun, S.; Liu, J.; Sun, X.; Zhu, W.; Yang, F.; Felczak, L.; Dou, Q.P.; Zhou, K. Novel Annonaceous acetogenins from Graviola (Annona muricata) fruits with strong anti-proliferative activity. Tetrahedron Lett. 2017, 58, 1895-1899. [CrossRef]

22. World Health Organization (WHO). Guidelines for Laboratory and Field Testing of Mosquito Larvicides. Available online: https://apps.who.int/iris/bitstream/handle/10665/69101/WHO_CDS_WHOPES_GCDPP_ 2005.13.pdf;jsessionid=ACA4BF09EDE97BB1D53DF249203894E0? sequence=1 (accessed on 5 April 2018).

23. Suryawanshi, R.K.; Patil, C.D.; Borase, H.P.; Narkhede, C.P.; Salunke, B.K.; Patil, S.V. Mosquito larvicidal and pupaecidal potential of prodigiosin from Serratia marcescens and understanding its mechanism of action. Pestic. Biochem. Physiol. 2015, 123, 49-55. [CrossRef] [PubMed]

24. Rieser, M.J.; Gu, Z.-M.; Fang, X.-P.; Zeng, L.; Wood, K.V.; McLaughlin, J.L. Five Novel Mono-tetrahydrofuran Ring Acetogenins from the Seeds of Annona muricata. J. Nat. Prod. 1996, 59, 100-108. [CrossRef] [PubMed]

25. Mohankumar, T.K.; Shivanna, K.S.; Achuttan, V.V. Screening of Methanolic Plant Extracts against Larvae of Aedes aegypti and Anopheles stephensi in Mysore. J. Arthropod Borne Dis. 2016, 10, 303-314. [PubMed]

26. Kempraj, V.; Bhat, S.K. Acute and reproductive toxicity of Annona squamosa to Aedes albopictus. Pestic. Biochem. Physiol. 2011, 100, 82-86. [CrossRef]

27. Deomena, M.; Navarro, D.; DePaula, J.; Luna, J.; Ferreiradelima, M.; Santana, A. Larvicidal activities against Aedes aegypti of some Brazilian medicinal plants. Bioresour. Technol. 2007, 98, 2549-2556. [CrossRef]

28. Cavalca, P.A.M.; Lolis, M.I.G.D.A.; Reis, B.; Bonato, C.M. Homeopathic and larvicide effect of Eucalyptus cinerea essential oil against Aedes aegypti. Braz. Arch. Boil. Technol. 2010, 53, 835-843. [CrossRef]

29. Warikoo, R.; Ray, A.; Sandhu, J.K.; Samal, R.; Wahab, N.; Kumar, S. Larvicidal and irritant activities of hexane leaf extracts of Citrus sinensis against dengue vector Aedes aegypti L. Asian Pac. J. Trop. Biomed. 2012, 2, 152-155. [CrossRef]

30. De Morais, S.M.; Facundo, V.A.; Bertini, L.M.; Cavalcanti, E.S.B.; Júnior, J.F.D.A.; Ferreira, S.A.; De Brito, E.S.; Neto, M.A.D.S. Chemical composition and larvicidal activity of essential oils from Piper species. Biochem. Syst. Ecol. 2007, 35, 670-675. [CrossRef]

31. Kumar, S.; Nair, G.; Singh, A.P.; Batra, S.; Wahab, N.; Warikoo, R. Evaluation of the larvicidal efficiency of stem, roots and leaves of the weed, Parthenium hysterophorus (Family: Asteraceae) against Aedes aegypti L. Asian Pac. J. Trop. Dis. 2012, 2, 395-400. [CrossRef]

32. Subramaniam, J.; Kovendan, K.; Kumar, P.M.; Murugan, K.; Walton, W. Mosquito larvicidal activity of Aloe vera (Family: Liliaceae) leaf extract and Bacillus sphaericus, against Chikungunya vector, Aedes aegypti. Saudi J. Boil. Sci. 2012, 19, 503-509. [CrossRef] [PubMed]

33. Rahuman, A.A.; Gopalakrishnan, G.; Venkatesan, P.; Geetha, K. Larvicidal activity of some Euphorbiaceae plant extracts against Aedes aegypti and Culex quinquefasciatus (Diptera: Culicidae). Parasitol. Res. 2008, 102, 867-873. [CrossRef] [PubMed]

34. Bonneau, N.; Schmitz-Afonso, I.; Brunelle, A.; Touboul, D.; Champy, P. Method development for quantification of the environmental neurotoxin annonacin in Rat plasma by UPLC-MS/MS and application to a pharmacokinetic study. J. Chromatogr. B 2015, 1004, 46-52. [CrossRef] [PubMed]

35. De Mendonça, F.A.; Da Silva, K.; Dos Santos, K.; Júnior, K.R.; Sant'Ana, A. Activities of some Brazilian plants against larvae of the mosquito Aedes aegypti. Fitoterapia 2005, 76, 629-636. [CrossRef] [PubMed]

36. He, K.; Zeng, Q.Y.; Shi, G.; Oberlies, N.H.; Zhao, G.; Njoku, C.J.; Mclaughlin, J.L. Comparative SAR evaluations of annonaceous acetogenins for pesticidal acitivity. J. Pest Sci. 1997, 49, 372-378. [CrossRef]

37. Rodríguez-Cavallo, E.; Guarnizo-Méndez, J.; Yépez-Terrill, A.; Cárdenas-Rivero, A.; Diaz-Castillo, F.; Méndez-Cuadro, D. Protein carbonylation is a mediator in larvicidal mechanisms of Tabernaemontana cymosa ethanolic extract. J. King Saud Univ. Sci. 2018. [CrossRef]

38. Costa, M.D.S.; De Paula, S.O.; Martins, G.F.; Zanuncio, J.C.; Santana, A.E.G.; Serrão, J.E. Modes of action of squamocin in the anal papillae of Aedes aegypti larvae. Physiol. Mol. Plant Pathol. 2018, 101, 172-177. [CrossRef]

39. Santos, L.M.; Nascimento, J.S.; Santos, M.A.; Marriel, N.B.; Bezerra-Silva, P.C.; Rocha, S.K.; Silva, A.G.; Correia, M.T.; Paiva, P.M.; Martins, G.F.; et al. Fatty acid-rich volatile oil from Syagrus coronata seeds has larvicidal and oviposition-deterrent activities against Aedes aegypti. Physiol. Mol. Plant Pathol. 2017, 100, 35-40. [CrossRef] 
40. Wong, C.-L.; Ahmad, R.; Yu, K.-X.; Jantan, I. Larvicidal activity, inhibition effect on development, histopathological alteration and morphological aberration induced by seaweed extracts in Aedes aegypti (Diptera: Culicidae). Asian Pac. J. Trop. Med. 2015, 8, 1006-1012.

41. Koodalingam, A.; Mullainadhan, P.; Arumugam, M. Effects of extract of soapnut Sapindus emarginatus on esterases and phosphatases of the vector mosquito, Aedes aegypti (Diptera: Culicidae). Acta Trop. 2011, 118, 27-36. [CrossRef]

42. Shamsi, T.N.; Parveen, R.; Ahmad, A.; Samal, R.R.; Kumar, S.; Fatima, S. Inhibition of gut proteases and development of dengue vector, Aedes aegypti by Allium sativum protease inhibitor. Acta Ecol. Sin. 2018, 38, 325-328. [CrossRef]

(C) 2019 by the authors. Licensee MDPI, Basel, Switzerland. This article is an open access article distributed under the terms and conditions of the Creative Commons Attribution (CC BY) license (http://creativecommons.org/licenses/by/4.0/). 